\title{
IMPLEMENTASI MODEL PEMBELAJARAN ARCS (ATTENTION, RELEVANCE, CONFINDENCE, SATISFACTION) PADA MATERI LIMIT FUNGSI ALJABAR UNTUK MENINGKATKAN HASIL BELAJAR PESERTA DIDIK KELAS XI IPA SMA NEGERI 2 TANJUNG SELOR
}

\author{
SUPRATMAN \\ SMA Negeri 2 Tanjung Selor, Kalimantan Utara \\ Email : supratmanajalasse@gmail.com
}

\begin{abstract}
ABSTRAK
Penelitian ini adalah penelitian tindakan kelas yang bertujuan untuk meningkatkan hasil belajar matematika Peserta Didik kelas XI IPA SMA Negeri 2 Tanjung Selor melalui model pembelajaran ARCS (Attention, Relevance, Confidence, Satisfaction). Penelitian ini dilaksanakan selama dua Siklus. Data yang terkumpul dianalisis dengan menggunakan analisis kualitatif dan analisis kuantitatif. Berdasarkan hasil analisis data tentang hasil belajar Peserta Didik diperoleh skor rata-rata untuk siklus I untuk ranah kognitif ialah 70,06, ranah afektif berada pada kategori baik, dan untuk ranak psikomotor berada pada kategori cukup dan kategori baik. Pada siklus II skor rata-rata yang diperoleh untuk ranah kognitif ialah 92,88 untuk ranah afektif berada pada kategori baik, dan untuk ranah psikomotor berada pada kategori sangat baik. Selain itu diperoleh data menurut lembar observasi tentang keaktifan Peserta Didik pada saat pembelpelajaran di mana pada siklus I keaktifan Peserta Didik yang memberi perhatian terutama saat guru menyampaikan tujuan pembelpelajaran dan menjelaskan materi, berdiskusi dengan teman kelompok dan menyelesaikan soal, mempresentasikan hasil kerja kelompok serta keaktifan bertanya tentang materi yang belum dimengerti masih sangat kurang dan pada siklus II diperoleh data keaktifan Peserta Didik dalam memberi perhatian, berdiskusi dengan teman kelompok dan menyelesaikan soal, mempresentasikan hasil kerja kelompoknya serta keaktifan bertanya tentang materi yang dimengerti sudah lebih baik dari siklus I. Dengan memperhatikan peningkatan hasil belajar dan keaktifan Peserta Didik dari siklus I ke siklus II dengan menerapkan model pembelaharan ARCS (Attention, Relevance, Confidence, Satisfaction) maka model pembelpelajaran ARCS (Attention, Relevance, Confidence, Satisfaction) dapat meningkatkan hasil belajar matematika Peserta Didik kelas XI IPA.1 SMA Negeri 2 Tanjung Selor.
\end{abstract}

Kata kunci: Penelitian Tindakan Kelas, Hasil Belajar, Model Pembelpelajaran ARCS (Attention, Relevance, Confidence, Satisfaction)

\section{PENDAHULUAN}

Matematika sebagai ratu atau ibunya ilmu dimaksudkan bahwa matematika adalah sebagai sumber dari ilmu lain. Dengan perkataan lain, banyak ilmu-ilmu yang penemuan dan pengembangannya bergantung dari matematika. Sebagai contoh, banyak teori-teori dan cabangcabang dari fisika dan kimia (modern) yang ditemukan dan dikembangkan melalui konsep kalkulus, khususnya persamaan diferensial; penemuan dan pengembangan teori mendel dalam biologi melalui konsep probabilitas; teori ekonomi mengenai permintaan dan penawaran yang dikembangkan melalui konsep fungsi dan kalkulus tentang diferensial dan integral (Suherman, 2003: 25).

Namun, matematika sering dianggap sebagai mata pelajaran yang sulit dan membosankan bagi peserta didik. Sebagaimana yang diungkapkan oleh Mulyati (Wahyudin : 2008) bahwa matematika merupakan mata pelajaran yang sulit untuk dipelajari. Hal tersebut membuat peserta didik kurang tertarik dengan matematika, dan kemudian akan mempengaruhi hasil belajar peserta didik.

Berdasarkan hasil observasi dan hasil analisis penilaian ujian akhir semester ganjil tahun 2018/2019, 80\% nilai matematika peserta didik kelas XI IPA masih rendah di bawah Kriteria Ketuntasan Minimum (KKM) yang ideal yaitu 68 terutama pada materi aljabar dan Kalkulus. 
Dari segi proses, peneliti sudah lama merasa menghadapi masalah dalam mengajar matematika diantaranya: 1) peserta didik kurang tertarik pada pelajaran dan menganggap pelajaran matematika sangat sulit; 2) setiap masuk kelas, ada peserta didik di kelas tersebut yang tidak hadir dengan alasan tidak masuk akal; 3) peserta didik cenderung kurang aktif dalam pembelajaran matematika, para peserta didik jarang mengajukan pertanyaan walaupun guru sering meminta peserta didik untuk bertanya; 4) respon peserta didik terhadap pendapat temannya sangat kurang; dan 5) selama pelajaran berlangsung banyak peserta yang tidak memperhatikan pelajaran, bahkan ada beberapa peserta didik yang mengantuk.

Berdasarkan pengamatan dan hasil observasi yang dilakukan, diidentifikasi beberapa kemungkinan penyebab munculnya masalah tersebut di atas sebagai berikut: 1) soal-soal yang diberikan terlalu sulit dipahami siswa, ada soal yang diberikan soal hots, yang masih asing bagi peserta didik; 2) model mengajar yang masih monoton, dimana masih menggunakan model yang sama dalam setiap pembelajaran matematika sehingga matematika yang memang sudah dianggap sulit bagi peserta didik terasa semakin tidak menarik; dan 3) para peserta didik jarang mengajukan pertanyaan walaupun guru sering meminta peserta didik untuk bertanya, hal ini disebabkan karena peserta didik terkadang merasa takut kepada gurunya, tidak percaya diri, serta tidak berani mengambil resiko.

Untuk mengatasi permasalahan tersebut diperlukan suatu model pembelajaran yang tepat dan menarik dimana peserta didik dapat bertanya pada guru secara langsung, mengemukakan pendapat, serta membuat peserta didik tetap melakukan kegiatan belajar, baik di sekolah maupun di lingkungan luar sekolah seperti rumah, sehingga peserta didik yang kurang paham terhadap materi yang disampaikan akan menjadi lebih mengerti karena adanya latihan yang dilakukan secara rutin.

Dalam hal ini peneliti menganggap model pembelajaran ARCS (Attention, Relevance, Confidence, Satisfaction) sangat membantu peserta didik untuk meningkatkan hasil belajar peserta didik. Model pembelajaran ini dibagi menjadi empat bagian yaitu: attention (perhatian), relevance (relevansi), confidence (kepercayaan diri), satisfaction (kepuasan). Pada pembelajaran ini, peserta didik dibawa untuk mengikuti proses belajar yang menyenangkan. Mula-mula pembelajaran ditekankan pada ketertarikan peserta didik dengan lingkungan peserta didik. Langkah selanjutnya adalah menumbuhkan kepercayaan diri peserta didik, misalnya dengan cara peserta didik mengemukakan pendapat dan ide-idenya, dan langkah terakhir adalah memberikan pujian, memberikan hadiah atau memberikan nilai yang bagus sebagai upaya menimbulkan kepuasan pada diri peserta didik. Dalam penelitian yang dilakukan oleh Sulistiyani (2012) dengan judul efektivitas pembelajaran ARCS (Attention, Relevance, Confidence, Satisfaction) berbantuan alat peraga terhadap peningkatan hasil belajar matematika peserta didik pokok bahasan segiempat menyatakan bahwa kemampuan pemecahan masalah peserta didik yang di beri perlakuan pembelajaran ARCS (Attention, Relevance, Confidence, Satisfaction) lebih efektif dari pada peserta didik yang diberi perlakuan pembelajaran konvensional.

\section{METODE PENELITIAN}

Prosedur penelitian yang digunakan dalam penelitian ini adalah penelitian tindakan kelas. Rancangan yang digunakan adalah model rancangan yang diadaptasi Stephen Kemmis dan Mc. Taggart (1998) dengan menggunakan dua siklus, dengan masing-masing siklus terdiri dari empat tahapan yaitu: (1) perencanaan, (2) tindakan, (3) observasi dan evaluasi, dan (4) refleksi.

Berikut ini adalah gambar rancangan penelitian tindakan kelas menurut Stephen Kemmis dan Mc. Taggart (1998) terlihat pada gambar 1 di bawah ini. 
TEACHING : Jurnal Inovasi Keguruan dan IImu Pendidikan

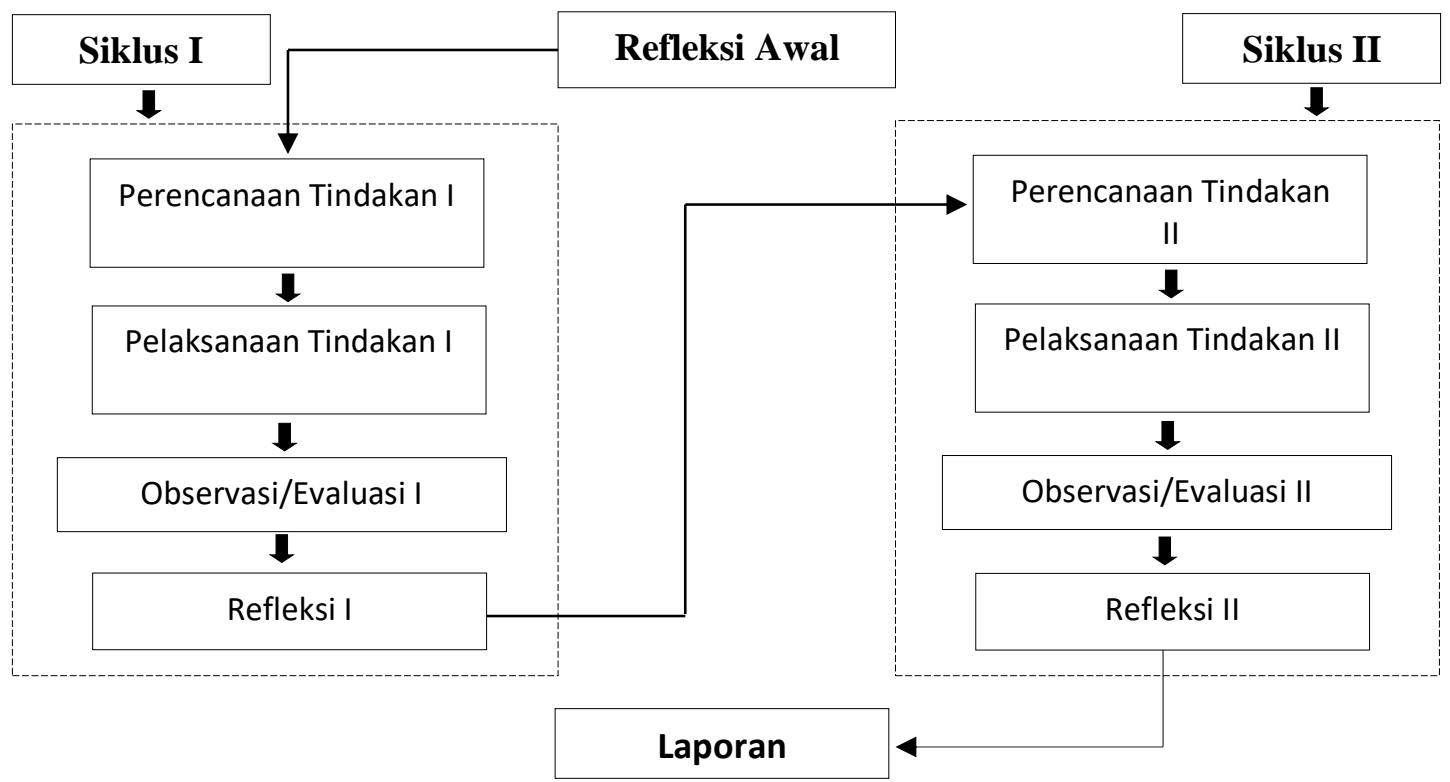

Gambar 1. Rancangan penelitian tindakan kelas

Pada siklus pertama (siklus I) sesuai dengan skema yang telah ditetapkan dilakukan beberapa tahapan: tahap (1) Perencanaan Pada tahap ini peneliti menelaah silabus mata pelajaran matematika,membuat perangkat pembelajaran untuk setiap pertemuan, membuat tes siklus I ,lembar observasi, dan angket respon peserta didik sebagai instrument, berkonsultasi dengan teman sejawat membuat instrumen. Pada tahap menyusun rancangan diupayakan ada kesepakatan antara guru dan sejawat.. Tahap (2) Tahap Pelaksanaan tindakan dilakukan dengan empat kali pertemuan. Pada pembelajaran dikelas guru peneliti menerapkan pendekatan scientic dengan model pembelajaran ARCS. Rancangan tindakan tersebut sebelumnya telah dilatih untuk dapat diterapkan di dalam kelas sesuai dengan skenarionya. Skenario dari tindakan diupayakan dilaksanakan dengan baik dan wajar. Tahap (3) Tahap ini sebenarnya berjalan bersamaan dengan saat pelaksanaan. Pengamatan dilakukan pada waktu tindakan sedang berjalan, jadi, keduanya berlangsung dalam waktu yang sama. Pada tahap ini, guru yang bertindak sebagai peneliti melakukan pengamatan dan mencatat semua hal yang diperlukan dan terjadi selama pelaksanaan tindakan berlangsung. Pengumpulan data ini dilakukan dengan menggunakan belajar yang telah tersusun, termasuk juga pengamatan secara cermat pelaksanaan skenario tindakan dari waktu ke waktu serta dampaknya terhadap proses dan hasil belajar siswa, dan (4) Tahapan ini dimaksudkan untuk mengkaji secara menyeluruh tindakan yang telah dilakukan, berdasarkan data yang telah terkumpul, kemudian dilakukan evaluasi guna menyempurnakan tindakan berikutnya. Refleksi dalam PTK mencakup analisis, sintesis, dan penilaian terhadap hasil pengamatan atas tindakan yang dilakukan. Jika terdapat masalah dari proses refleksi maka dilakukan proses pengkajian ulang melalui siklus berikutnya yang meliputi kegiatan: perencanaan ulang, tindakan ulang, dan pengamatan ulang shingga permasalahan dapat teratasi.

Pada Siklus II ini dilaksanakan selama dua kali pertemuan. Pada dasarnya langkahlangkah yang dilakukan dalam siklus II ini mengacu pada hasil refleksi, selanjutnya dikembangkan dan dimodifikasi tahapan-tahapan yang ada pada siklus I dengan beberapa perbaikan dan penambahan sesuai dengan kenyataan yang ditemukan. Selanjutnya pada tahap terakhir guru peneliti melakukan refleksi tentang hasil aktivitas belajar peserta didik selama proses pembelajaran dan post tes (tes hasil belajar) pada akhir siklus. 


\section{HASIL DAN PEMBAHASAN}

\section{a. Hasil Penelitian}

\section{Siklus I pertemuan pertama}

Pada pertemuan pertama siklus I sub pokok bahasan yang diajarkan adalah konsep Limit Fungsi Aljabar. Hal pertama yang peneliti lakukan adalah menyiapkan kelas dengan mempersilahkan ketua kelas untuk menyiapkan teman-temannya dengan mengucapkan salam, berdoa bersama. Setelah itu guru mengecek kehadiran peserta didik. Selanjutnya guru menceritakan pentingnya materi yang akan dipelajari dan sejarah dari Limit Fungsi Aljabar. Kemudian, guru mengingatkan kembali pada peserta didik sebagai materi prasyarat sebelum memasuki materi Limit Fungsi Aljabar. Selanjutnya guru menyampaikan kompetensi inti, kompetensi dasar, indikator pembelajaran, tujuan pembelajaran, model pembelajaran yang akan digunakan selama pembelajaran berlangsung.

Pada pembahasan materi awal, peneliti mengawali penyampaian materi konsep Limit Fungsi Aljabar dengan membahas beberapa masalah (hal. 218-228) pada buku paket peserta didik bersama peserta didik sambil menumbuhkan perhatian pada aktivitas menanya dan mengamati. Kemudian guru menyampaikan inti materi pembelajaran mengenai konsep limit Fungsi Aljabar secara jelas. Selanjutnya peserta didik mengerjakan LKPD yang telah diberikan oleh peneliti. Setelah itu, salah satu kelompok kedepan kelas untuk mempresentasikan hasil kerja kelompoknya. Akan tetapi, pada pertemuan ini tidak ada satupun kelompok atau peserta didik yang menanggapi hasil kerja kelompok yang dipresentasikan. Peserta didik masih terlihat canggung dan tidak berani untuk menanggapi hasil kerja kelompok temannya.

\section{Siklus I pertemuan kedua}

Sub pokok bahasan yang dipelajari adalah Sifat -Sifat Limit Fungsi Aljabar. Pada pertemuan kedua peneliti melaksanakan kegiatan pembelajaran yang pada dasarnya sama dengan pertemuan pertama. Guru membahas masalah pada hal. (228-235) selanjutnya menjelaskan inti materi kemudian memberikan LKPD untuk kemudian setiap peserta didik mengerjakan dan mendiskusikan dengan teman sekelompoknya. Namun pada pertemuan kedua ini peneliti lebih memaksimalkan pengelolahan pembelajaran untuk mengatasi masalah pada pertemuan pertama. Pada pertemuan ini semua peserta didik serius dengan kelompok mereka masing-masing untuk mengerjakan LKPD yang diberikan oleh guru. Ketika guru meminta kelompok untuk mempresentasikan hasil kerja kelompok, terlihat beberapa kelompok yang mengajukan diri untuk mempresentasikan hasil kerja kelompok mereka dan ketika peserta didik diminta untuk menanggapi terdapat 2 orang peserta didik yang menanggapi dengan alasan berbeda hasil kerja. Namun, ketika pemberian tes pada akhir pertemuan masih terlihat ada peserta didik yang kurang senang dan mengeluh ketika diberikan tes.

\section{Siklus I pertemuan ketiga}

Sub pokok bahasan yang dipelajari adalah Nilai Limit Fungsi. Pada pertemuan ini peneliti melaksanakan kegiatan pelajaran yang pada dasarnya sama dengan pertemuan sebelumnya. Namun pada pertemuan ini juga ada peningkatan pada aktivitas peserta didik. Terlihat peserta didik antusias dalam mengerjakan Lembar Kerja Peserta didik (LKPD) yang diberikan oleh guru. Ketika peserta didik diminta mengacungkan tangan untuk mempresentasikan hasil kerjanya, semua kelompok mengacungkan tangan dan bersedia untuk mempresentasikan hasil kerjanya dan ketika diberikan tes uraian tidak ada lagi seruan atau keluhan dari peserta didik. Semua peserta didik mengerjakan tes uraian dengan tenang.

\section{Siklus I pertemuan keempat}

Pada pertemuan ke empat guru melakukan tes akhir siklus 1 kemudian hasil tes dianalisis secara deskriptif.. 
Berdasarkan hasil pengamatan/observasi dan hasil tes selama proses pembelajaran Siklus I dapat dilihat pada Tabel 1.

Tabel 1. Distribusi Nilai Hasil Belajar peserta didik Pada Siklus 1

\begin{tabular}{|c|l|c|}
\hline No. & \multicolumn{1}{|c|}{ Uraian } & Hasil Siklus 1 \\
\hline 1. & Nilai Tertinggi & 96 \\
2. & Nilai Terendah & 40 \\
3. & Nilai rata-rata tes hasil belajar & 70,06 \\
4. & Jumlah peserta didik yang tuntas belajar & 17,00 \\
5. & Jumlah peserta didik yang tidak tuntas & 14.00 \\
6. & Persentase ketuntasan belajar & $54 \%$ \\
\hline
\end{tabular}

Berdasarkan pada tabel 1 di atas, dapat diketahui bahwa hasil belajar peserta didik kelas XI IPA yang mengikuti pembelajaran dengan penerapan model ARCS diperoleh nilai rata-rata hasil belajar matematika wajib sebesar 70,06 dan ketuntasan belajar 54\% atau ada 17 peserta didik dari 31 peserta didik sudah tuntas belajar. Hasil ini menunjukkan bahwa secara klasikal peserta didik belum tuntas belajar, karena peserta didik yang memperoleh nilai $\geq 70$ (KKM) hanya sebesar 70,06\% lebih kecil dari prosentase ketuntasan yang dikehendaki yaitu sebesar $85 \%$.

Berdasarkan hasil refleksi siklus pertama (siklus I) diketahui bahwa tidak tercapainya ketuntasan aktivitas belajar peserta didik disebabkan karena peserta didik masih asing dengan model pembelajaran yang digunakan. Ada beberapa peserta didik yang enggan bertanya dan menanggapi hasil presentasi temannya. Umumnya para peserta didik acuh tak acuh terhadap penjelasan guru ketika guru menyampaikan tujuan pembelajaran, kompetensi inti, kompetensi dasar, dan indikator pembelajaran bahkan masih terlihat pada saat guru menjelaskan materi inti pelajaran. Hal ini dapat dilihat dengan kurangnya tanggapan atau diskusi terhadap materi pelajaran yang diberikan pada saat penelitian ini berlangsung.

Oleh karena itu peneliti merasa perlu melakukan perbaikan tindakan terhadap proses pembelajaran yang telah dilakukan pada siklus pertama (siklus I) dengan lebih mendekatkan diri kepada peserta didik, membimbing peserta didik secara individual maupun kelompok, guru lebih mengawasi peserta didik mengerjakan latihan, di samping itu guru membantu peserta didik secara intensif terutama peserta didik yang pasif.

\section{Siklus II Pertemuan Pertama}

Pada pertemuan pertama siklus II sub pokok bahasan yang diajarkan adalah Konsep Limit fungsi bentuk tak hingga. Hal yang peneliti lakukan tidak jauh berbeda dengan pengajaran pada siklus I. Peneliti membuka pelajaran, mengecek kehadiran peserta didik selanjutnya peneliti menjelaskan kompetensi inti, kompetensi dasar, dan indikator pembelajaran, serta menjelaskan model pembelajaran yang akan digunakan selama pembelajaran berlangsung.

Guru menjelaskan inti dari materi Limit Fungsi bentuk tak hingga dengan membahas bersama masalah yang relevan dengan kehidupan sehari-hari yang terdapat pada buku paket. Setelah itu, peserta didik berdiskusi dalam kelompoknya masing-masing. Semua peserta didik terlihat antusias dalam mengerjakan soal-soal dalam LKPD. Semua peserta didik ingin mempresentasikan hasil kerja mereka. Guru memberikan kesempatan kepada peserta didik dalam mengerjakan latihan pada LKPD, peserta didik mengoreksi hasil kerja teman kelompoknya dan guru mengamati aktivitas peserta didik sambil membimbing peserta didik dalam memperbaiki hasil pekerjaannya.

\section{Siklus II Pertemuan Kedua}

Pada Pertemuan kedua, Peneliti membuka pelajaran, mengecek kehadiran peserta didik selanjutnya peneliti meberikan tes akhir siklus II.

Berdasarkan hasil pengamatan/observasi dan hasil tes selama proses pembelajaran Siklus II dapat dilihat pada Tabel 2. 
Tabel 2. Distribusi Nilai Hasil Belajar peserta didik Pada Siklus 2

\begin{tabular}{|c|l|c|}
\hline No. & \multicolumn{1}{|c|}{ Uraian } & Hasil Siklus 2 \\
\hline 1. & Nilai Tertinggi & 100 \\
2. & Nilai Terendah & 71 \\
3. & Nilai rata-rata tes hasil belajar & 85,09 \\
4. & Jumlah peserta didik yang tuntas belajar & 31,00 \\
5. & Jumlah peserta didik yang tidak tuntas & 00.00 \\
6. & Persentase ketuntasan belajar & $100 \%$ \\
\hline
\end{tabular}

Berdasarkan pada tabel 2 di atas, dapat diketahui bahwa hasil belajar peserta didik kelas XI IPA yang mengikuti pembelajaran dengan penerapan model pembelajaran ARCS diperoleh nilai rata-rata hasil belajar seni Matematika wajib sebesar 85,09 dan ketuntasan belajar 100\% atau semua peserta didik sudah tuntas belajar. Hasil ini menunjukkan bahwa secara klasikal peserta didik sudah tuntas belajar, dan sudah memenuhi syarat karena jumlah peserta didik yang telah mencapai nilai $\geq 70(\mathrm{KKM})$ sebanyak $100 \%$ dan berada diatas kriteria ketuntasan klasikal $85 \%$, maka penelitian ini berakhir di siklus kedua 2. Perbandingan hasil belajar peserta didik pada sikus 1 dengan siklus 2 ditunjukkan pada Tabel 3.

Tabel. 3 Perbandingan hasil belajar peserta didik pada siklus 1 dan siklus 2

\begin{tabular}{|c|l|c|c|}
\hline No. & \multicolumn{1}{|c|}{ Uraian } & Hasil Siklus 1 & Hasil Siklus 2 \\
\hline 1. & Nilai Tertinggi & 96 & 100 \\
2. & Nilai Terendah & 40 & 71 \\
3. & Nilai rata-rata tes hasil belajar & 70,06 & 85,09 \\
4. & Jumlah peserta didik yang tuntas belajar & 17,00 & 31,00 \\
5. & Jumlah peserta didik yang tidak tuntas & 14.00 & 00.00 \\
6. & Persentase ketuntasan belajar & $54 \%$ & $100 \%$ \\
\hline
\end{tabular}

Berdasarkan pada tabel 3 di atas, dapat diketahui bahwa hasil belajar peserta didik kelas XI IPA yang mengikuti pembelajaran dengan penerapan model pembelajaran ARCS mengalami peningkatan dari siklus I ke Siklus 2 sebesar 15,03\% dari rata-rata 70,06 pada siklus I menjadi 85,09 pada siklus II. Sedangkan ketuntasan klasikal mengalami peningkatan sebesar $46 \%$ dari KK $54 \%$ menjadi KK $100 \%$ pada siklus II.

\section{b. Pembahasan}

Pada siklus I diperoleh hasil belajar dengan nilai rata-rata sebesar 70, 06 dan nilai yang diperoleh sudah berada pada kategori sangat tinggi yaitu frekuensi peserta didik sebanyak 3 orang dari jumlah peserta didik, pada kategori tinggi frekuensi peserta didik sebanyak 3 orang, pada kategori sedang frekuensi peserta didik sebanyak 17 orang, namun masih ada beberapa peserta didik berada pada kategori sangat rendah dan rendah yaitu 4 peserta didik dengan kategori rendah dan 4 peserta didik dengan kategori rendah. Sedangkan ketuntasan hasil belajar peserta didik diperoleh $45 \%$ dengan jumlah frekuensi sebanyak 14 orang dari jumlah peserta didik yang dikategorikan tidak tuntas dan 54\% dengan jumlah frekuensi 17 orang dari jumlah peserta didik dikategorikan tuntas. Dari hasil ini dapat dinyatakan bahwa ketuntasan belajar peserta didik secara maksimal belum tercapai. Hal ini disebabkan sebagian peserta didik masih kurang keaktifannya dalam memberikan perhatian pada saat pembelajaran, demikian juga peserta didik yang mengajukan pertanyaan dan tanggapan yang masih sangat kurang, dan sebagian peserta didik yang masih kurang untuk mampu menyimpulkan pelajaran. Selain itu, peserta didik yang tampil di papan tulis menyelesaikan soal latihan masih kurang dan beberapa peserta didik cenderung untuk malu bertanya tentang materi yang belum di mengerti. Disamping itu, ada dari beberapa peserta didik yang masih belum memahami model pembelajaran yang digunakan dalam pembelajaran. Namun demikian, terjadi peningkatan hasil belajar peserta didik dari sebelum menggunakan model pembelajaran ARCS (Attention, 
Relevance, Confidence, Satisfaction) dan setelah menggunakan model pembelajaran ARCS (Attention, Relevance, Confidence, Satisfaction). Hal ini sesuai dengan hasil meta analisis metode pembelajaran yang dilakukan oleh Soedomo,1990 (dalam Puger, 2004) yang menyatakan bahwa metode pembelajaran yang diterapkan oleh seorang guru berpengaruh terhadap hasil belajarnya.

Pada siklus II diperoleh hasil belajar dengan nilai rata-rata sebesar 85,09 dan nilai yang diperoleh berada pada kategori tinggi sebesar 35\% dengan jumlah frekuensi 11 orang dari jumlah peserta didik dan 39\% dengan jumlah frekuensi 12 orang dari jumlah peserta didik berada pada kategori sangat tinggi. Dan 26\% dengan jumlah frekuensi 8 orang berada pada kategori sedang. Sedangkan ketuntasan hasil belajar peserta didik diperoleh $100 \%$ dengan jumlah frekuensi 31 orang dari jumlah dikategorikan. Dari hasil ini dapat dinyatakan bahwa ketuntasan belajar peserta didik secara klasikal sudah tercapai karena menurut ketentuan Depdiknas dan disesuaikan di sekolah SMA Negeri 2 Tanjung Selor bahwa peserta didik dikatakan tuntas belajar jika memperoleh skor minimal 68 dari skor ideal, dan tuntas secara klasikal apabila $80 \%$ dari jumlah peserta didik yang telah tuntas belajar sehingga penelitian tidak dilanjutkan lagi pada siklus berikutnya.

Dari hasil penelitian menunjukkan adanya peningkatan hasil nilai awal, nilai siklus I dan nilai siklus II, yaitu dari rata-rata nilai awal adalah 68 naik di siklus I menjadi 70,06 dan di siklus II naik menjadi 85,09. Untuk ketuntasan klasikal juga mengalami kenaikan dari $54 \%$ pada siklus I menjadi $100 \%$ pada siklus II. Hal ini sejalan pula dengan temuan-temuan peneliti lain seperti yang dilakukan oleh Inten (2004) dan Puger (2004) yang pada dasarnya menyatakan bahwa metode pembelajaran yang diterapkan berpengaruh terhadap hasil belajar siswa. Dengan demikian dapat dikatakan penerapan model pembelajaran ARCS (Attention, Relevance, Confidence, Satisfaction) dapat meningkatkan hasil belajar peserta didik pada materi limit fungsi aljabar di kelas XI IPA. Pembelajaran model pembelajaran ARCS (Attention, Relevance, Confidence, Satisfaction) sangat membantu guru meningkatkan kualitas pembelajaran di kelas terutama dalam mengajarkan materi limit fungsi aljabar maupun materi lainnya.

\section{KESIMPULAN}

Sesuai hasil penelitian dan pembahasan, maka dapat dikemukakan bahwa setelah dilakukan tindakan dengan menggunakan penerapan model pembelajaran ARCS (Attention, Relevance, Confidence, Satisfaction) pada peserta didik kelas XI IPA SMA Negeri 2 Tanjung Selor semester genap tahun pelajaran 2018/2019 terjadi perubahan penguasaan materi limit fungsi aljabar. Perubahan ini nampak pada hasil observasi maupun pos test yang didapat dari pre tindakan, tindakan pada siklus I, dan tindakan dari siklus II. Data perkembangan hasil peningkatan hasil belajar peserta didik dapat dilihat dari rata-rata perolehan nilai peserta didik pada masing-masing siklus mengalami peningkatan yakni pada siklus 1 rata-rata hasil belajar 70,06 pada siklus 1 menjadi 85,09 pada siklus 2. Persentase ketuntasan belajar juga mengalami peningkatan dari 54\% pada siklus 1 menjadi $100 \%$ pada siklus 2. Dengan hasil penelitian ini, penulis menyarankan kiranya rekan-rekan guru yang lain dapat mencoba menerapkan model pembelajaran ARCS (Attention, Relevance, Confidence, Satisfaction) pada materi lain yang lebih kompleks.

\section{DAFTAR PUSTAKA}

Chairani, Zahrah. (2005). Model ARCS dalam Pembelajaran. Kalimantan. Widyaiswara LPMP Kalimantan Selatan.

Dahar, Wills. (1998). Teori-teori Belajar. Jakarta: Erlangga.

Hadis, Abdul. (2006). Psikologi Dalam Pendidikan. Bandung: Alfabeta Bandung.

Manullang,Sudianto dkk. (2017). Matematika SMA/MA/SMK/MAK KELAS XI. Jakarta: Kemendikbud. 
Mulyati. (2013). Peningkatan Kemampuan Pemahaman Dan Representasi Matematis Siswa SMA Melalui Strategi PreviewQuestion-Rea Reflekt Recite Review. Skripsi. Universitas Pendidikan Indonesia. repository.upi.edu. 01 Juli 2014

Puger, I Gusti Ngurah. (2004). Belajar Kooperatif. Diktat Perkuliahan Mahasiswa Unipas.

Rusma. (2010). Model-Model Pembelajaran. Bandung: Rajawali Pers.

Siregar, Evelina \& Nara, Hartini. (2010). Teori Belajar dan Pembelajaran: Jakarta. Ghalia Indonesia.

Suherman, Erman dkk. (2003). Strategi Matematika Kontemporer. Bandung: Jurusan Pendidikan Matematika FMIPA Universitas Pendidikan Indonesia.

Sulistiyani. (2011). Efektivitas Pembelajaran ARCS (Attension, Relevance, Confidence, Satisfaction) Berbantu Alat Peraga Terhadap Peningkatan Hasil Belajar Matematika Peserta Didik Pada Pokok Bahasan Segiempat. Skripsi. Fakultas Tarbiyah Institut Agama Islam Negeri Walisongo Semarang.

Syaodih, Nana. (2009). Landasan Psikologi Proses Pendidikan: Bandung, Remaja Rosdakarya Bandung.

Uno, Hamzah B. (2007). Model Pembelajaran "menciptakan proses belajar yang kreatif dan efektif": Jakarta, Bumi Aksara. 